NBER WORKING PAPER SERIES

\title{
A SHRED OF CREDIBLE EVIDENCE ON THE LONG RUN ELASTICITY OF LABOR SUPPLY
}

\author{
Orley C. Ashenfelter
}

Kirk B. Doran

Bruce Schaller

Working Paper 15746

http://www.nber.org/papers/w15746

\author{
NATIONAL BUREAU OF ECONOMIC RESEARCH \\ 1050 Massachusetts Avenue \\ Cambridge, MA 02138 \\ February 2010
}

We are indebted to Henry Farber, Derek Neal, John Pencavel, Robert Solow, and to participants at the Conference in Honour of Richard Layard and Steve Nickell held at the Center for Economic Performance in June of 2009 for very helpful comments on this paper. We are also indebted to Nicholas Lawson for outstanding research assistance and to the Industrial Relations Section at Princeton University for financial support. The views expressed herein are those of the authors and do not necessarily reflect the views of the National Bureau of Economic Research.

NBER working papers are circulated for discussion and comment purposes. They have not been peerreviewed or been subject to the review by the NBER Board of Directors that accompanies official NBER publications.

(C) 2010 by Orley C. Ashenfelter, Kirk B. Doran, and Bruce Schaller. All rights reserved. Short sections of text, not to exceed two paragraphs, may be quoted without explicit permission provided that full credit, including $\odot$ notice, is given to the source. 
A Shred of Credible Evidence on the Long Run Elasticity of Labor Supply

Orley C. Ashenfelter, Kirk B. Doran, and Bruce Schaller

NBER Working Paper No. 15746

February 2010

JEL No. H31,J22

\begin{abstract}
Virtually all public policies regarding taxation and the redistribution of income rely on explicit or implicit assumptions about the long run effect of wages rates on labor supply. The available estimates of the wage elasticity of male labor supply in the literature have varied between -0.2 and 0.2 , implying that permanent wage increases have relatively small, poorly determined effects on labor supplied. The variation in existing estimates calls for a simple, natural experiment in which men can change their hours of work, and in which wages have been exogenously and permanently changed. We introduce a panel data set of taxi drivers who choose their own hours, and who experienced two exogenous permanent fare increases instituted by the New York City Taxi and Limousine Commission, and we use these data to fit a simple structural labor supply function. Our estimates suggest that the elasticity of labor supply is about -0.2 , implying that income effects dominate substitution effects in the long run labor supply of males.
\end{abstract}

Orley C. Ashenfelter

Center for Labor Economics

University of California

631B Evans Hall

Berkeley, CA 94720-3880

and NBER

c6789@ princeton.edu

Kirk B. Doran

438 Flanner Hall

University of Notre Dame

Notre Dame, IN 46556

kdoran@nd.edu
Bruce Schaller

Department of Transportation

55 Water St.

New York, NY 10041

bruceschaller@earthlink.net 


\section{Introduction}

The effect of wage rates on long run labor supply is a key ingredient in the discussion of virtually all public policies regarding taxation, social safety nets, and the redistribution of income. Although there is a relatively broad consensus that the long run elasticity of labor supply is not likely to be large, especially for adult males, this consensus is a result of many individual studies that face a litany of familiar limitations. ${ }^{1}$ The two most serious problems in studying worker preferences between income and leisure that modern studies face are (a) the inability of most workers to alter their hours of work without changing jobs and (b) the consequent inability of the analyst to measure exogenous changes in wages that workers face. Our goal in this paper is to provide a straightforward analysis of the labor supply of workers whose hours are flexible in response to an exogenous wage increase. To do this we have deliberately selected data for a group where a transparent econometric analysis is feasible, rather than apply more complex methods to a broad based and representative data set. Needless to say, our approach has the obvious advantage of transparency, while suffering from the disadvantage that it may not be appropriate to generalize our findings to other populations.

Our analysis relies on a new panel dataset of New York City taxi drivers who choose their own work hours, and who experienced two exogenous, permanent increases in their real wages. New York taxi drivers either own or lease taxi “medallions,” which

\footnotetext{
${ }^{1}$ See the comprehensive and influential surveys by Pencavel (1986), Heckman and Killingsworth (1986), and Blundell and MaCurdy (1999) for the details. Formal evidence that workers face constraints on hours worked within jobs dates from at least Ham (1982) and Altonji and Paxson (1988).
} 
give them the right to collect passengers when hailed on the street, subject to a number of rules and regulations, including the fees they may charge. This economic environment provides a straightforward method for estimating the labor supply response to a wage change, if one occurs. Our data indicate that work responses to exogenous increases in the fare structure are small, and negative. Worker wages, on the other hand, are strongly affected by increases in the fare structure. Taken together the evidence implies that the long run uncompensated elasticity of labor supply lies around -.2, and that it may be estimated in our data with considerable precision.

Taxi drivers have been the subject of several studies that attempt to use the time series behavior of individual drivers who face stable fare structures to study intertemporal substitution and reference dependence in driver preferences. (See Farber (2005) and the references therein.) However, absent the observation of exogenous, permanent wage changes, these papers cannot measure long run labor supply parameters and they do not attempt to do so.

In the next section of the paper we provide a brief discussion of the New York City taxi industry. We then introduce our new data set on taxi revenues and fares, set out a simple theoretical model of taxi driver incentives, and discuss the empirical results. The final section contains some brief concluding remarks and indicates some of the implications of our findings for future research.

\section{Taxis in New York}


There are five main types of cabs in New York City: yellow taxis, car services, black cars, limousines, and illegal so-called gitney cabs. ${ }^{2}$ Only yellow cabs are legally allowed to accept passengers from street hails, and this - along with hails from passengers waiting in lines at airports, train stations, and hotels - is the only legal source of passengers for yellow cabs. All taxi and livery services are regulated by the New York City Taxi and Limousine Commission (TLC).

In 2006, there were 12,779 yellow taxis in New York City, out of a total of about 46,000 legal taxis, car service, and black car vehicles. The yellow taxis concentrate on serving Manhattan residents, who are transported in $71 \%$ of their trips. As of 2002, "twothirds of Manhattan residents used cabs for work and/or personal trips at least some of the time,” and overall, "Manhattan adults hail a cab an average of 100 times a year” (Schaller 2006). In turn, "90\% of all taxi trips originate in Manhattan” (Schaller 2006). Yellow taxis are thus an important part of the Manhattan transportation system, with " 8.5 yellow ... taxis per 1,000 Manhattan residents in 2005” (Schaller 2006).

The only way to legally drive a yellow taxi is with a taxi license: “a painted aluminum medallion ... which is affixed to the hood of every yellow ... cab” (Schaller 2006). The number of medallions is determined by the TLC, and has not varied much from around 12,000 for the past 60 years. There are three main ways to get access to a medallion: (1) buying one on the open market; (2) renting one for long-term periods of time as a "named driver"; and (3) renting a medallion one shift at a time as an "unnamed driver.” Individually-owned cabs are now required to "be driven 210 shifts per year by the medallion owner, for licenses transferred since 1990," although there is some question about whether the required number of shifts is enforced (Schaller 2006).

\footnotetext{
${ }^{2}$ A comprehensive source, on which we rely for much of the following material, is Bruce Schaller (2006).
} 
The TLC also sets the fares that taxis must charge. A taxi trip begins with a fare drop: a large charge that is accrued as soon as the cab drives for more than a short distance (this distance has ranged from $1 / 7$ to $1 / 5$ of a mile since 1952). After this, the passengers are charged for mileage (when the cab is moving more than $12 \mathrm{mph}$ ) and wait time (when the cab is stopped or moving less than $12 \mathrm{mph}$ ). Finally, there are and have been various surcharges for trips beginning during certain times of the day, and various flat fares for trips to and/or from specific airports.

Since July 1952, the TLC has changed the fares 13 times. In nominal dollars, the fare drop has increased from $\$ 0.25$ for the first $1 / 5$ mile to $\$ 2.50$ for the first $1 / 5$ mile, the charge per mile has increased from $\$ 0.20$ to $\$ 2.00$, and the charge per minute has increased from $\$ 0.03$ to $\$ 0.40$. Average fares have increased from $\$ 0.83$ to $\$ 9.61$.

The recent fare increases analyzed in this paper (March 1996 and May 2004) have resulted in increased total revenue per hour (i.e., the number of passengers hailing cabs did not decline enough to offset additional revenue from higher fares per trip), which suggests that the demand for taxis is inelastic. It is possible to interpret some of these fare increases as accounting for inflation, however after the 2004 fare increase, drivers' real cash incomes exceeded "driver incomes in 1929 for the first time since the Crash" (Schaller 2006). This suggests that there have been long-term changes in drivers' real net hourly wages that have been precipitated in part by nominal fare changes instituted by the TLC.

In the next section, we discuss the data we use to analyze the response of taxicab drivers to two changes in real revenue per mile that were brought about by the 1996 and 2004 fare increases. 


\section{Data}

The City of New York’s Taxi and Limousine Commission (TLC) inspects each yellow taxicab three times a year at its central inspection facility. The data used in this paper is the TLC's complete set of official inspection records from September 1994 through December 2005. Each inspection record includes the medallion number, the registered type of driving arrangement (owner-driver, owner-driver with another driver, named driver, or unnamed driver), the odometer reading, the taximeter reading, and the date of the inspection. From these data, we can calculate the number of days since the last inspection (always about 4 months), the month in which the inspection took place (to capture seasonal effects), the number of miles driven since the last inspection, and the revenue earned since the last inspection.

The measure of labor supply that we construct from these data is the number of miles driven. With a constant average speed (which we take to be driver specific in the analysis below), miles driven is a good measure of hours worked, and thus of labor supply. However, it should be clear that although hours worked and miles driven are highly related, they are not identical. The primary difference will be due to waiting time that results in passenger revenue, but that does not result from miles being driven. We suspect that the primary place where this happens is where cabs are waiting in a line at an airport or a hotel, for the purpose of shuttling passengers between the two. However, as of 1990, only four percent of all yellow taxi trips began or ended in La Guardia or Kennedy airports (the number at Newark airport was negligible). (Schaller 2006) This 
implies that most taxi drivers are probably cruising on Manhattan streets when they are looking for a passenger, so that miles driven and hours worked will be closely related. ${ }^{3}$

The corresponding real net revenue earned per mile driven in a given four month period is the real revenue earned during that period minus the real costs, divided by the number of miles driven. We use as our measure of the real earnings from driving a mile the real revenues divided by the number of miles driven. Holding velocity and real costs constant, the average real revenue per mile is proportional to the average hourly wage. In the interest of holding real costs constant, which we presume are primarily fixed, we exclude from our sample all medallions that are being leased by their drivers (named drivers, and unnamed drivers), since real lease rates change over time.

Since we are interested in estimating the labor supply of taxi drivers, not of taxicabs, we would like each observation to be for a particular driver. To help achieve this, we also exclude from our sample all medallions owned by a driver who rents out his medallion to another driver for the complementary shifts. Finally, we exclude from our data set all records in which the inspection took place more than 365 days before one of the fare increases, records in which the inspection took place less than four months after one of the fare increases (this eliminates inspection periods that straddle both sides of the fare increase), and records in which the inspection took place more than four months plus 365 days after a fare increase.

We are left with a total of 19,134 observations (inspections) of 2,637 medallions, where each medallion at any point in time is driven by an individual owner-driver. ${ }^{4}$

\footnotetext{
${ }^{3}$ The potential linkage between driver labor supply and miles driven would ideally be studied with some measure of actual hours worked or clocked, which is not available at this time. However, in our analyses we do control for driver fixed effects and for month variability and it seems likely that much of the systematic variation in driver down time that otherwise exists will be unrelated to the timing of fare changes.
} 
These observations cover the labor supplied by these drivers from: March 1st, 1995 through February $9^{\text {th }}, 1996$; from July $1^{\text {st }}, 1996$ through July $1^{\text {st }}, 1997$; from May $12^{\text {th }}$ 2003 through May 3 ${ }^{\text {rd }}, 2004$; and from September $7^{\text {th }}, 2004$ through September $7^{\text {th }}, 2005$. Our data covers an average of 825 days for each medallion, with a standard deviation of 368 days.

We do not know with certainty that each observation represents the work of one driver, since the driver associated with a medallion at the beginning of an inspection period may have sold his medallion before the next inspection. We also do not know for sure that the driver associated with a medallion in one year is necessarily the same driver associated with that medallion in another year. However, we do know the total number of taxi medallion sales each month from January 1990 through December 2005. On average, only 18 exchanges of privately-owned medallions occur each month, meaning that within the average inspection period less than three percent of medallions change hands. Some of these should actually involve sales to corporations that lease medallions, thus removing drivers from our sample, not matching new drivers to existing medallions. Our medallion fixed effects are thus only a proxy for driver-level fixed effects. Since at most three percent of these medallions changed hands in any given period, most medallions must have stayed in the hands of the same owner drivers during the small periods of time before and after each fare change, which implies that our primary analysis should not be affected.

We report summary statistics from these data in Table 1 , and a very simple prepost analysis of differences in miles driven and revenue received per mile in Table 2a (the full panel) and Table 2b (a balanced subset of the full panel). The basic data

\footnotetext{
${ }^{4}$ Only 2,535 of these medallions have sufficient meter information for revenue and related calculations.
} 
surrounding the fare structure increases are also reported in Figures 1 and 2. It is clear from the figures that the real average revenue per mile was higher in the three years after each fare change than in the years before, suggesting that we can measure the labor supply response of owner-drivers to changes in real wages using the fare changes as an instrument. The figures also are consistent with only a small, and perhaps negative, permanent change in miles driven in response to the fare changes. Taken at face value, the simple division of the proportionate change in miles driven by the proportionate change in revenue per mile provides a measure of the uncompensated labor supply elasticity. For the balanced sample of data these estimates are all roughly $-5 \% / 20 \%=-.25$. As we shall see below, this is close to the estimate obtained from a more complete econometric analysis.

\section{A Simple Model of Behavior for Taxi Driver Labor Supply}

What is apparent from the previous discussion is that drivers do not face explicit wage rates, but instead face a taxi fare function that relates their income to hours worked through the miles they travel. A simple model of this behavior starts with the standard assumption that a driver has utility function

(1) $u=u(h, y)$,

where $\mathrm{h}$ is hours worked and $\mathrm{y}$ is income from driving, and $\mathrm{u}_{\mathrm{h}}<0, \mathrm{u}_{\mathrm{y}}>0$. A worker also faces a schedule relating work to income

(2) $y=g(h ; \theta)$,

where $\theta$ represents the parametric part of the fare structure. The driver optimizes by working at a point where 


\section{(3) $-u_{h} / u_{y}=g_{h}$,}

the rate of substitution of leisure for goods equals the marginal effect of hours on income.

A convenient parameterization to the rate of substitution function $-\mathrm{u}_{\mathrm{h}} / \mathrm{u}_{\mathrm{y}}$ is $-\mathrm{u}_{\mathrm{h}} /$ $\mathrm{u}_{\mathrm{y}}=\alpha \mathrm{h}^{\beta}$, while $\mathrm{g}(\mathrm{h} ; \theta)=\theta \mathrm{h}$ is a first order approximation for the earnings function, and we can thus measure $\theta$ as revenue per mile driven. The function $\alpha h^{\beta}$ captures the notion that whether the uncompensated labor supply function is positively or negatively sloped depends on whether the rate of substitution of leisure for goods increases or decreases at higher work hours. ${ }^{5}$ There is nothing in the conventional theory of labor/leisure choice that compels either to be the case, so that the issue is entirely an empirical one.

These assumptions lead to a supply function of the form

(4) $\ln (\mathrm{h})=(1 / \Re) \ln \theta-\ln (\alpha / ß)$,

which is a straightforward log linear regression. In principle, in this setup fixed effects for individual drivers have the interpretation as variation in $\alpha$, which affects the level of hours worked, but does not affect the response of hours worked with respect to the wage rate. Note that because of our linear approximation $g(h, y)=\theta h$, we are assuming that individual drivers face perfectly elastic demand schedules for hours worked. ${ }^{6}$

Our estimation strategy is straightforward. We first fit reduced from equations for revenue per mile $(\theta)$ and miles driven (h) as functions of monthly dummy variables for the month in which an inspection is observed, a measure of the number of days since the previous inspection, and an indicator for the fare structure in place. We then fit the labor

\footnotetext{
${ }^{5}$ This functional form was first apparently used by Burtless and Hausman (1978) and the implied utility function and other aspects of it are discussed extensively by Stern (1986).

${ }^{6}$ It is important to understand that, even though the demand curve for aggregate taxi rides is downward sloping, this is not the demand curve that individual drivers face Our assumption about the driver's revenue function implies that an individual driver may drive as much as they like at the equilibrium price in the aggregate market.
} 
supply function (4) by ordinary least squares and also using the fare indicator variables as instruments. In this context, the fare structure instruments serve two purposes. They permit us both to identify a shift along a labor supply function from an exogenous shift in the wage, and they also serve to correct for measurement error that results from the “division” bias produced from the way we construct our measure of revenue per mile. ${ }^{7}$

\section{Empirical Results}

Our identification of the effect of the wage rate on labor supply depends on observing an exogenous wage increase that is not confounded by other factors that would affect labor supply. We use exogenous fare increases for this purpose. It is hard to imagine precisely what other factors would be likely to serve as confounding factors. Factors such as unpredictable increases in the demand for taxi rides (as from a spontaneous demand shock) would not be permanent, while most other shocks would be related to the seasonal or individual driver fixed effects for which we control. ${ }^{8}$

\section{(A) The Uncompensated Wage-Elasticity of Labor Supply}

We report the first stage results of regressing revenue/ per mile driven on the fare dummy variables and some other control variables in Table 3. It is apparent that the fare increases are associated with an average $19 \%$ increase in revenue per mile, and that this effect is precisely measured. It is also notable that both the month dummies and the

\footnotetext{
${ }^{7}$ This measurement error tends to produce an automatic negative correlation between miles driven and revenue per mile, because the former is contained in the denominator of the latter. Measurement errors in miles driven thus results in a spurious negative correlation between miles driven and revenue per mile. See especially Farber (2005) for a discussion of this issue.

${ }^{8}$ One exception might be gasoline prices, which is an important cost for a driver. However, gasoline prices were very stable in the period surrounding the 1996 fare increase. Gasoline prices were on an increasing path during the period surrounding the 2004 fare increase, which would imply that we have somewhat underestimated the increase in real revenues per mile driven and therefore underestimated (in absolute value) the labor supply elasticity.
} 
“days since inspection” variables have very small coefficients, implying that reporting month deviations in revenue per mile are typically within 1 to 3 percent. $^{9}$

We also report the reduced from regression of miles driven on the fare dummy variables and some other control variables in Table 4. The results indicate that miles driven decline from 2 to 4 percent following a fare increase, depending on the specification. The more appropriate specification, which controls for medallion fixed effects, indicates an average 4.2 percent decline in miles driven. In this exactly identified model, the ratio of these two reduced from estimates is precisely our instrumental variables estimate.

The instrumental variables estimates are reported in Table 5. In what we consider the most appropriate specification, using fixed effects, we estimate an uncompensated labor supply elasticity of -.23 , with a standard error only about one-tenth that size. This is our preferred estimate of these drivers' uncompensated wage-elasticity of labor supply and it is estimated with considerable precision.

There are two other determinants of labor supply that might well have changed at the same time that the fare changed and as a result of its change: (a) the drivers' incentive to rent their medallion to others may have increased because of the increased medallion rental rate, and (b) the value of the medallion on the medallion transaction market may have increased. We examine these issues in order to see what, if any, effect they may have on the interpretations of our primary empirical results.

(B) The Change in the Medallion Rental Rate.

\footnotetext{
${ }^{9}$ Recall from the discussion above that the "month" dummy variables record the month that the taxi inspection took place. These inspections cover a 4 month period. Thus, the coefficients on the month dummies are linear combinations of effects that would be estimated with dummy variables that measured the revenue per mile in an actual calendar month.
} 
We do not observe the medallion rental rates over time. However, we know that in 1996 the TLC raised the cap medallion lease, but that in 2004 the TLC only raised the cap medallion lease rate by $8 \%$ in order that most of the fare increase "would end up in drivers’ pockets.” (See the timeline in the appendix for more details.) Although we cannot document all the details there is a potential for large changes in the lease rate around the time of the fare changes that might affect the labor supply of drivers who owned medallions, despite the fact that these lease rates do not affect them directly, because of the potential incentives a change in the lease rate might give an owner driver.

For example, this change in the incentive to lease to others could potentially cause at least one serious bias: it could selectively remove people from our sample after the fare increase, because they then start renting their evening shift to others.

Since our data set has the universe of drivers inspected by the TLC between 1990 and 2005 we may examine the number of medallions that switched from being associated with an owner-driver to being associated with both an owner-driver and another driver, after the fare increases were announced. The data on switchers shows that this type of selection affected less than one percent of our sample ${ }^{10}$. Thus, it seems unlikely that increased medallion renting has any effect on our results.

(C) The Change in the Price of the Medallion

The New York City taxi medallion is a major asset. In December 2005, the average nominal transaction price in the market for individual medallions was $\$ 350,000$.

\footnotetext{
${ }^{10}$ There are 17 medallions in our sample that were owner-driver medallions as of March 2004, but became medallions associated with both an owner-driver and another driver after March 2004 (i.e., after the announcement of the fare increase). Assuming that all of these drivers sought out partners because of the increased lease rates, this would mean that the selection rate was 17 out of the total of 2705 medallions in our sample. According to our data, no medallions that were associated only with an owner-driver before the 1996 fare increase later appear as associated with an owner-driver and another driver after the 1996 fare increase. Dividing 17 over 2705 gives a selection rate of under 1\%.
} 
A change in the medallion's value occurring at the same time as the fare change could lead to two biases: (a) it could selectively remove people from our sample, because they sell their medallion in response to the jump in its value; and (b) for those who remain in our sample, it might affect their labor supply via an additional income effect. We can examine the selections issue (a) by looking at the number of individually-owned medallions sold around the time of the fare changes. We regress the number of medallions sold per month on the dummy for post-fare-increase and on month-of-theyear dummies. In results not reported, we find that the fare increases are associated with an extra 1.4 medallions sold per month, or 17 extra per year, and the increase is not statistically significant. This point estimate thus suggests that perhaps $1 \%$ of our sample selected to leave through selling their medallions, which seems unlikely to affect our results.

Finally, to examine possible income effects due to medallion price increases we examined the time series of monthly average medallion prices reported in Schaller (2006). Medallions trade in an open, public market and the prices are likely to be affected by many factors, including whether the City increases their supply, which they do from time to time (see the Timeline in the appendix), and on caps that the TLC places on lease rates. Clearly both the former and the latter are likely to drive prices down. The time series around the 1996 fare increase does not provide any evidence of medallion price increases, but the time series around the 2004 fare is more suggestive. It is clear that starting around September 2001 there was an upward trend in the price of medallions. It is clear that between September 2001 and April 2004 (when the new fare was announced), the trend in prices was almost linear, whereas as soon as the new fare 
took effect in May, the trend began to be broken. Fitting the data between September 2001 and April 2004 to a linear time trend shows that a rate of increase of $\$ 1,834$ per month gives an R-squared of 0.95 . This trend may thus represent a good counterfactual for what would have happened if the fare change had not been implemented. Using this counterfactual, we calculate that by December 2005, when our data set ends, the medallions were priced at $\$ 53,000$ more than they would have been without the fare change.

Is a $\$ 50,000$ increase in the value of a medallion likely to affect the continuing labor supply of an owner-driver separately from the wage increase with which it is associated? The answer to this question depends on the foresight and age of a driver. To the extent that the owner-driver continues to work and expects to do so for a long time, the income effect produced by the fare increase is entirely captured by the observed fare increase, just as any permanent wage increase affects a worker’s lifetime income. However, for workers with shorter horizons, there may be other effects.

.According to revenue information from our data set and cost information from The 2006 New York City Taxi Fact Book, the drivers in our sample could expect to generate net earnings of about $\$ 50,000$ per year over the course of their careers, so the medallion price increase is about equivalent to a single year of pay. Assuming an average career length of 30 years, the medallion price increase would constitute about $3 \%$ of lifetime income, while the medallion price increase would increase lifetime income by only about 3\%. This suggests that any direct effects of the medallion price increase on driver-owner labor supply will be small. 


\section{Conclusions}

Our results imply that the uncompensated labor supply elasticity for taxi drivers is almost certainly negative and small. This will come as no surprise to those who know the extensive literature devoted to the study of male labor supply. In addition, this finding is consistent with a broad variety of historical evidence that suggests that the massive increases in real wages seen in the United States and Europe since 1879 have been accompanied by significant declines in annual hours worked per worker. It is also consistent with the evidence that work hours are longer in poorer countries than in richer ones.

An important limitation of our results is that they capture only one margin on which labor supply is adjusted, neglecting especially issues of labor force participation and retirement. These participation issues may loom especially large for groups whose attachment to the labor force is not as strong as the primarily adult male workers who make up the bulk of taxi drivers.

Our results have important implications for much of the continuing discussion of tax and transfer programs in many countries. Many of these discussions continue to operate in nearly complete ignorance of the extensive scientific evidence about labor supply behavior that has been accumulated over the last four decades. No doubt this is a product, in part, of wishful thinking, but results like those in this paper, replicated in a variety of settings, might serve as a useful antidote for those who are prepared to examine the facts. 


\section{References}

Altonji, Joseph G and Paxson, Christina H, (1988) "Labor Supply Preferences, Hours Constraints, and Hours-Wage Trade-Offs," Journal of Labor Economics, University of Chicago Press, vol. 6(2), pages 254-76, April.

Blundell, Richard and MaCurdy, Thomas. (1999) "Labor supply: A review of alternative approaches," in O. Ashenfelter \& D. Card (ed.), Handbook of Labor Economics, edition 1, volume 3, chapter 27, pages 1559-1695 Elsevier.

Gary Burtless and Hausman, Jerry A.(1978) “The Effect of Taxation on Labor Supply: Evaluating the Gary Negative Income Tax Experiment,” The Journal of Political Economy, Vol. 86, No. 6 (Dec.), pp. 1103-1130

Farber, Henry (2005). Is Tomorrow Another Day? The Labor Supply of New York City Cab Drivers," Journal of Political Economy 113 (February 2005), pp. 46-82.

Ham, John (1982). "Estimation of a Labour Supply Model with Censoring due to Unemployment and Underemployment.” Review of Economic Studies, Vol. 49 (3), 1982, pp. 335-354.

Pencavel, John, 1986. “Labor Supply of Men: A Survey,” in: O. Ashenfelter \& R. Layard (ed.), Handbook of Labor Economics, volume 1, chapter 1, pages 3-102 Elsevier

Schaller, Bruce (2006). The New York City Taxicab Fact Book. Schaller Consulting, Brooklyn, NY.

Stern, Nicholas (1986) “On the Specification of Labour Supply Functions,” in: Blundell, Richard and Walker, Ian, (eds.) Unemployment, Search and Labour Supply. Cambridge University Press, Cambridge, UK, pp. 143-189 
Table 1: Simple Statistics

Simple Statistics: by inspection

\begin{tabular}{|c|c|c|c|c|c|}
\hline Variable & Mean & Std. Dev. & Min & Max & Obs \\
\hline $\begin{array}{l}\text { owner-driver? } \\
(1=\text { yes, } 0=\text { no })\end{array}$ & 0.49 & 0.50 & 0 & 1 & 102275 \\
\hline $\begin{array}{l}\text { Days since the last } \\
\text { inspection }\end{array}$ & 122 days & 4 days & 40 days & 237 days & 102275 \\
\hline $\begin{array}{l}\text { Miles driven since the last } \\
\text { inspection }\end{array}$ & $\begin{array}{c}15989 \\
\text { miles }\end{array}$ & $\begin{array}{l}6163 \\
\text { miles }\end{array}$ & $\begin{array}{l}4000 \\
\text { miles }\end{array}$ & $\begin{array}{l}41997 \\
\text { miles }\end{array}$ & 102275 \\
\hline Miles driver per day & $\begin{array}{l}131 \text { miles } \\
\text { per day }\end{array}$ & $\begin{array}{l}50 \text { miles } \\
\text { per day }\end{array}$ & $\begin{array}{l}24 \text { miles } \\
\text { per day }\end{array}$ & $\begin{array}{l}408 \text { miles } \\
\text { per day }\end{array}$ & 102275 \\
\hline $\begin{array}{l}\text { Revenue earned since the } \\
\text { last inspection }\end{array}$ & $\$ 21,597$ & $\$ 8,465$ & $\$, 3007$ & $\$ 68,536$ & 67317 \\
\hline Revenue earned per day & $\begin{array}{l}\$ 177 \text { per } \\
\text { day }\end{array}$ & $\begin{array}{l}\text { \$69 per } \\
\text { day }\end{array}$ & $\begin{array}{l}\$ 25 \text { per } \\
\text { day }\end{array}$ & $\begin{array}{l}\$ 553 \text { per } \\
\text { day }\end{array}$ & 67317 \\
\hline $\begin{array}{l}\text { Revenue earned per mile } \\
\text { (a measure of the wage) }\end{array}$ & $\begin{array}{l}\$ 0.68 \text { per } \\
\text { mile }\end{array}$ & $\begin{array}{l}\$ 0.14 \text { per } \\
\text { mile }\end{array}$ & $\begin{array}{l}\$ 0.33 \text { per } \\
\text { mile }\end{array}$ & $\begin{array}{l}\$ 1.41 \text { per } \\
\text { mile }\end{array}$ & 65888 \\
\hline $\begin{array}{l}\text { Real revenue earned per } \\
\text { mile (in December } 2005 \\
\text { Dollars) }\end{array}$ & $\begin{array}{l}\$ 0.81 \text { per } \\
\text { mile }\end{array}$ & $\begin{array}{l}\$ 0.14 \text { per } \\
\text { mile }\end{array}$ & $\begin{array}{l}\$ 0.44 \text { per } \\
\text { mile }\end{array}$ & $\begin{array}{l}\$ 1.56 \text { per } \\
\text { mile }\end{array}$ & 49112 \\
\hline
\end{tabular}

\section{Simple Statistics: by medallion}

\begin{tabular}{l|ccccc} 
Variable & Mean & Std. Dev. & Min & Max & Obs \\
\hline $\begin{array}{l}\text { owner-driver? } \\
(1=\text { yes, } 0=\text { no })\end{array}$ & 0.40 & 0.38 & 0 & 1 & 4658 \\
Number of Inspections & 22 & 12 & 1 & 46 & 4658
\end{tabular}


Table 2a: Simple Difference Table:

(Medallion Fixed Effects; no other controls)

\begin{tabular}{|l|lc|lc|}
\hline & \multicolumn{2}{|l|}{ Change in Revenue per Mile } & \multicolumn{2}{l|}{ Change in Miles Driven } \\
\hline 1996 Fare Increase & $+\$ 0.14$ & $(+17 \%)$ & -477 miles & $(-3.2 \%)$ \\
\hline 2004 Fare Increase & $+\$ 0.15$ & $(+19 \%)$ & -824 miles & $(-5.6 \%)$ \\
\hline
\end{tabular}

All changes are computed as the coefficient of a dummy variable indicating the year noted and are significant at the $0.1 \%$ level. Revenue is in December 2005 Dollars. Miles driven measures the number of miles driven since the last inspection. The average number of days between inspections is 122 (4 months) with a standard deviation of 4 days. Since the panel is not fully balanced, these results are computed from a regression that includes medallion fixed effects in order to use all the data.

\section{Difference Table:}

(Medallion Fixed Effects; controls for month and days since last inspection)

\begin{tabular}{|l|ll|ll|}
\hline & \multicolumn{2}{|l|}{ Change in Revenue per Mile } & \multicolumn{2}{l|}{ Change in Miles Driven } \\
\hline 1996 Fare Increase & $+\$ 0.14$ & $(+17 \%)$ & -399 miles & $(-2.7 \%)$ \\
\hline 2004 Fare Increase & $+\$ 0.15$ & $(+19 \%)$ & -818 miles & $(-5.6 \%)$ \\
\hline
\end{tabular}

All changes are computed as the coefficient of a dummy variable indicating the year noted and are significant at the $0.1 \%$ level. Revenue is in December 2005 Dollars. Miles driven measures the number of miles driven since the last inspection. The average number of days between inspections is 122 (4 months) with a standard deviation of 4 days. Since the panel is not fully balanced, these results are computed from a regression that includes medallion fixed effects in order to use all the data. The regressions in this table also contain a variable measuring the number of days since the taxi was last inspected. 
Table 2b: Simple Difference Table (Balanced Panel): (no other controls)

\begin{tabular}{|l|lc|ll|}
\hline & \multicolumn{2}{|l|}{ Change in Revenue per Mile } & \multicolumn{2}{l|}{ Change in Miles Driven } \\
\hline 1996 Fare Increase & $+\$ 0.15^{* * *}$ & $(+19.2 \%)$ & -819 miles* & $(-5.6 \%)$ \\
\hline 2004 Fare Increase & $+\$ 0.15^{* * *}$ & $(+20.9 \%)$ & -764 miles** & $(-5.1 \%)$ \\
\hline
\end{tabular}

Difference Table:

(controls for month and days since last inspection)

\begin{tabular}{|l|ll|ll|}
\hline & \multicolumn{2}{|l|}{ Change in Revenue per Mile } & \multicolumn{2}{l|}{ Change in Miles Driven } \\
\hline 1996 Fare Increase & $+\$ 0.15^{* * *}$ & $(+19.0 \%)$ & -758 miles* $^{*}$ & $(-5.2 \%)$ \\
\hline 2004 Fare Increase & $+\$ 0.15^{* * *}$ & $(+20.9 \%)$ & -758 miles $^{* *}$ & $(-5.1 \%)$ \\
\hline
\end{tabular}

All changes labeled with $* * *$ are significant at the $0.1 \%$ level; those with $* *$ are significant at the $1 \%$ level, and those with * at the $10 \%$ level. Revenue is in December 2005 Dollars. Miles driven measures the number of miles driven since the last inspection. The average number of days between inspections is 122.6 with a standard deviation of 3.86 days in 1996, and 121.7 with a standard deviation of 2.08 in 2004. 
Table 3: (Log) Revenue per Mile as a Function of the Fare Changes (First stages of specifications (2) and (4) in Table 5)

\begin{tabular}{lcc}
\hline & $(1)$ & $(2)$ \\
Post fare increase* & OLS & Fixed Effects \\
ln(days since inspection) & 0.19 & 0.19 \\
& $(0.00)$ & $(0.00)$ \\
February & -0.02 & -0.01 \\
& $(0.05)$ & $(0.03)$ \\
March & -0.01 & 0.01 \\
& $(0.01)$ & $(0.04)$ \\
April & -0.00 & -0.03 \\
& $(0.01)$ & $(0.04)$ \\
May & -0.02 & -0.06 \\
& $(0.01)$ & $(0.04)$ \\
June & 0.00 & 0.00 \\
& $(0.01)$ & $(0.01)$ \\
July & -0.01 & 0.00 \\
& $(0.01)$ & $(0.04)$ \\
August & -0.01 & -0.05 \\
& $(0.01)$ & $(0.04)$ \\
September & -0.03 & -0.07 \\
& $(0.01)$ & $(0.04)$ \\
October & -0.02 & -0.03 \\
& $(0.01)$ & $(0.00)$ \\
November & -0.04 & -0.02 \\
& $(0.01)$ & $(0.04)$ \\
December & -0.02 & -0.06 \\
& $(0.01)$ & $(0.04)$ \\
Constant & -0.03 & -0.07 \\
& $(0.01)$ & $(0.04)$ \\
Observations & -0.18 & -0.21 \\
R-squared & $(0.24)$ & $(0.15)$ \\
\# of Medallions & 12281 & 12281 \\
Standard errors & 0.24 & 0.53 \\
& & 2514 \\
\hline & &
\end{tabular}

Standard errors in parentheses

Unit of Observation:

Fixed Effects:

One Driver during a 4 month period Medallion Level

* Post fare increase $=0$ for inspections that take place during the 365 days before each fare change was implemented.

Post fare increase $=1$ for inspections that take place during the 365 days beginning four months after each fare change was implemented 
Table 4: (Log) Miles Driven as a Function of the Fare Changes

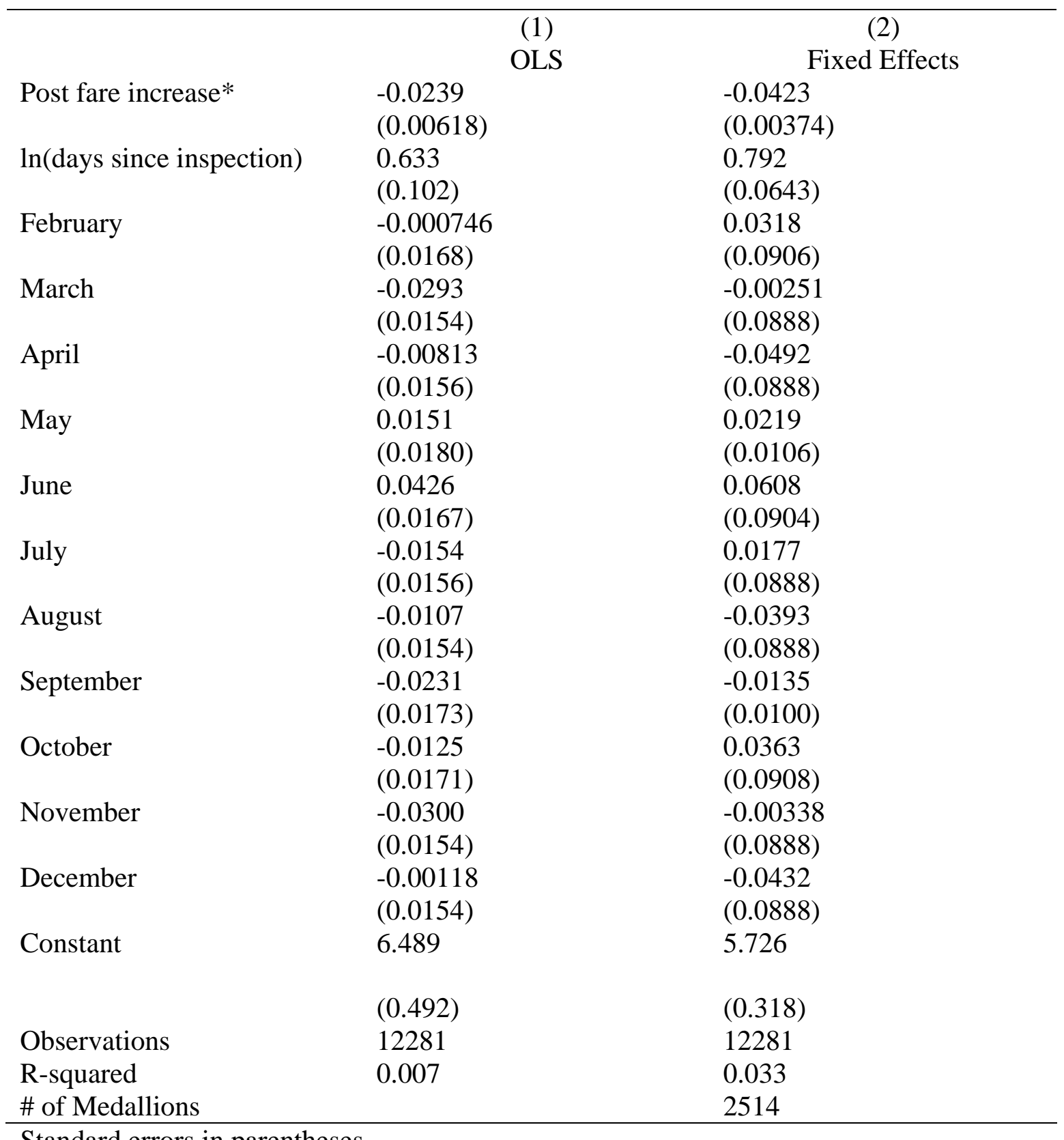

Standard errors in parentheses

Unit of Observation:

One Driver during a 4 month period

Fixed Effects:

Medallion Level

* Post fare increase $=0$ for inspections that take place during the 365 days before each fare change was implemented.

Post fare increase $=1$ for inspections that take place during the 365 days beginning four months after each fare change was implemented. 
Table 5: $(\log ()$ Miles Driven as a Function of $(\log )$ Revenue per Mile

\begin{tabular}{lcccc}
\hline & $(1)$ & $(2)$ & $(3)$ & $(4)$ \\
& OLS & OLS IV & Fixed Effects & Fixed Effects \\
In(real revenue/mile) & -0.42 & -0.13 & -0.40 & -0.23 \\
& $(0.01)$ & $(0.03)$ & $(0.01)$ & $(0.02)$ \\
In(days since inspection) & 0.63 & 0.63 & 0.72 & 0.79 \\
& $(0.06)$ & $(0.10)$ & $(0.04)$ & $(0.06)$ \\
February & 0.00 & -0.00 & 0.02 & 0.04 \\
& $(0.01)$ & $(0.02)$ & $(0.02)$ & $(0.09)$ \\
March & -0.03 & -0.03 & -0.00 & -0.01 \\
& $(0.01)$ & $(0.02)$ & $(0.02)$ & $(0.09)$ \\
April & -0.01 & -0.01 & -0.04 & -0.06 \\
& $(0.01)$ & $(0.02)$ & $(0.02)$ & $(0.09)$ \\
May & 0.02 & 0.02 & 0.02 & 0.02 \\
& $(0.01)$ & $(0.02)$ & $(0.01)$ & $(0.01)$ \\
June & 0.03 & 0.04 & 0.04 & 0.06 \\
& $(0.01)$ & $(0.02)$ & $(0.02)$ & $(0.09)$ \\
July & -0.01 & -0.02 & 0.02 & 0.01 \\
& $(0.01)$ & $(0.02)$ & $(0.02)$ & $(0.09)$ \\
August & -0.02 & -0.01 & -0.05 & -0.06 \\
September & $(0.01)$ & $(0.02)$ & $(0.02)$ & $(0.09)$ \\
& -0.02 & -0.03 & -0.02 & -0.02 \\
October & $(0.01)$ & $(0.02)$ & $(0.01)$ & $(0.01)$ \\
& -0.01 & -0.02 & -0.01 & 0.03 \\
November & $(0.01)$ & $(0.02)$ & $(0.02)$ & $(0.09)$ \\
& -0.04 & -0.03 & -0.02 & -0.01 \\
December & $(0.01)$ & $(0.02)$ & $(0.02)$ & $(0.09)$ \\
& -0.03 & -0.00 & -0.05 & -0.06 \\
Constant & $(0.01)$ & $(0.02)$ & $(0.02)$ & $(0.09)$ \\
Observations & 6.38 & 6.46 & 5.95 & 5.67 \\
R-squared & $(0.31)$ & $(0.48)$ & $(0.18)$ & $(0.31)$ \\
\# of Medallions & 33962 & 12281 & 33962 & 12244 \\
\hline Standard errors in parentheses & & 0.03 & 0.07 & \\
& 0.06 & & & 2514 \\
\hline & & & &
\end{tabular}

Standard errors in parentheses

Unit of Observation:

Instrument:

Fixed Effects:
One Driver during a 4 month period 1996 fare increase and 2004 fare increase Medallion Level 
Figure 1: How March 1996 fare change affected real revenue/mile and miles driven

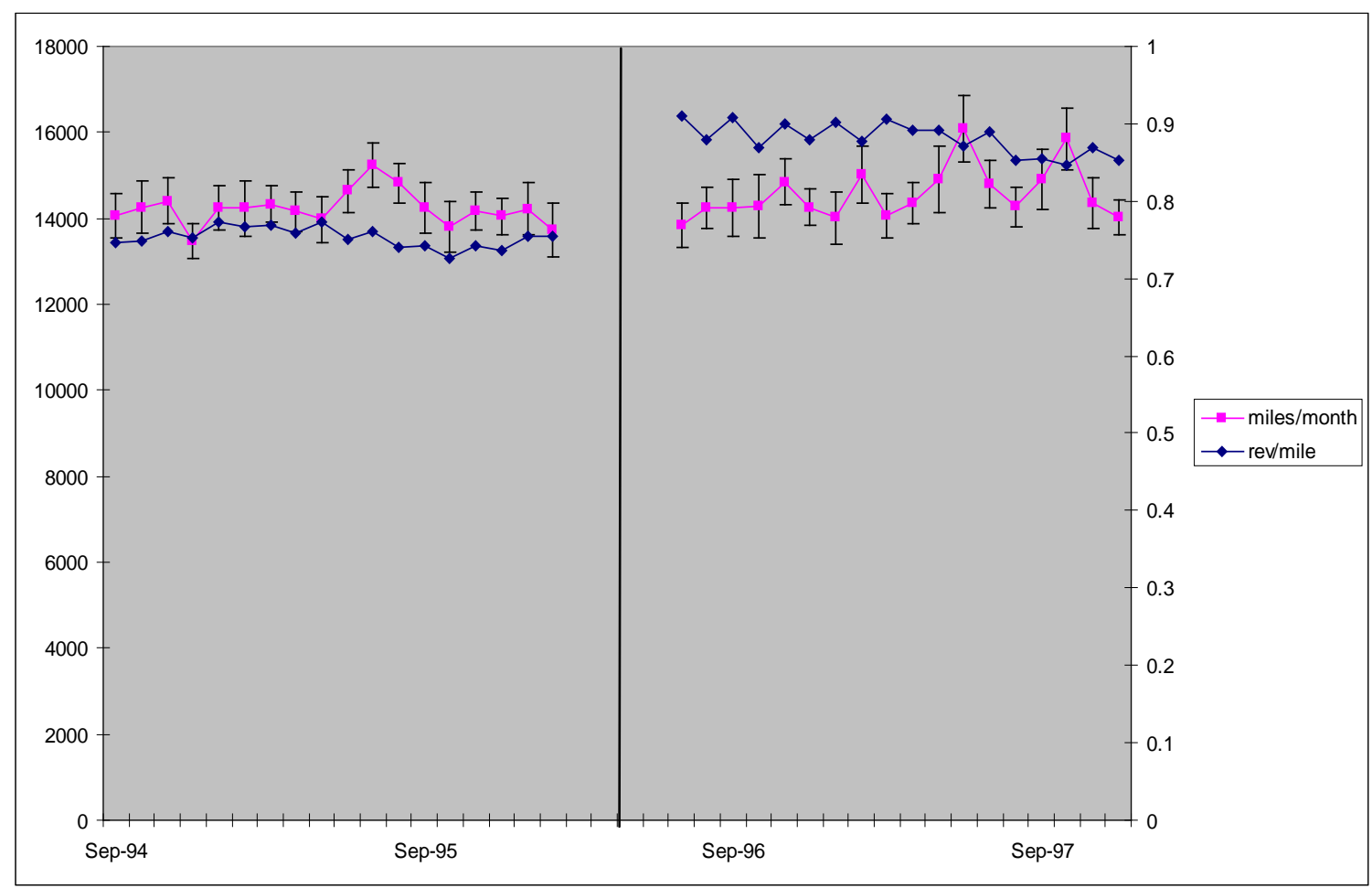

Figure 2: How May 2004 fare change affected real revenue/mile and miles driven 


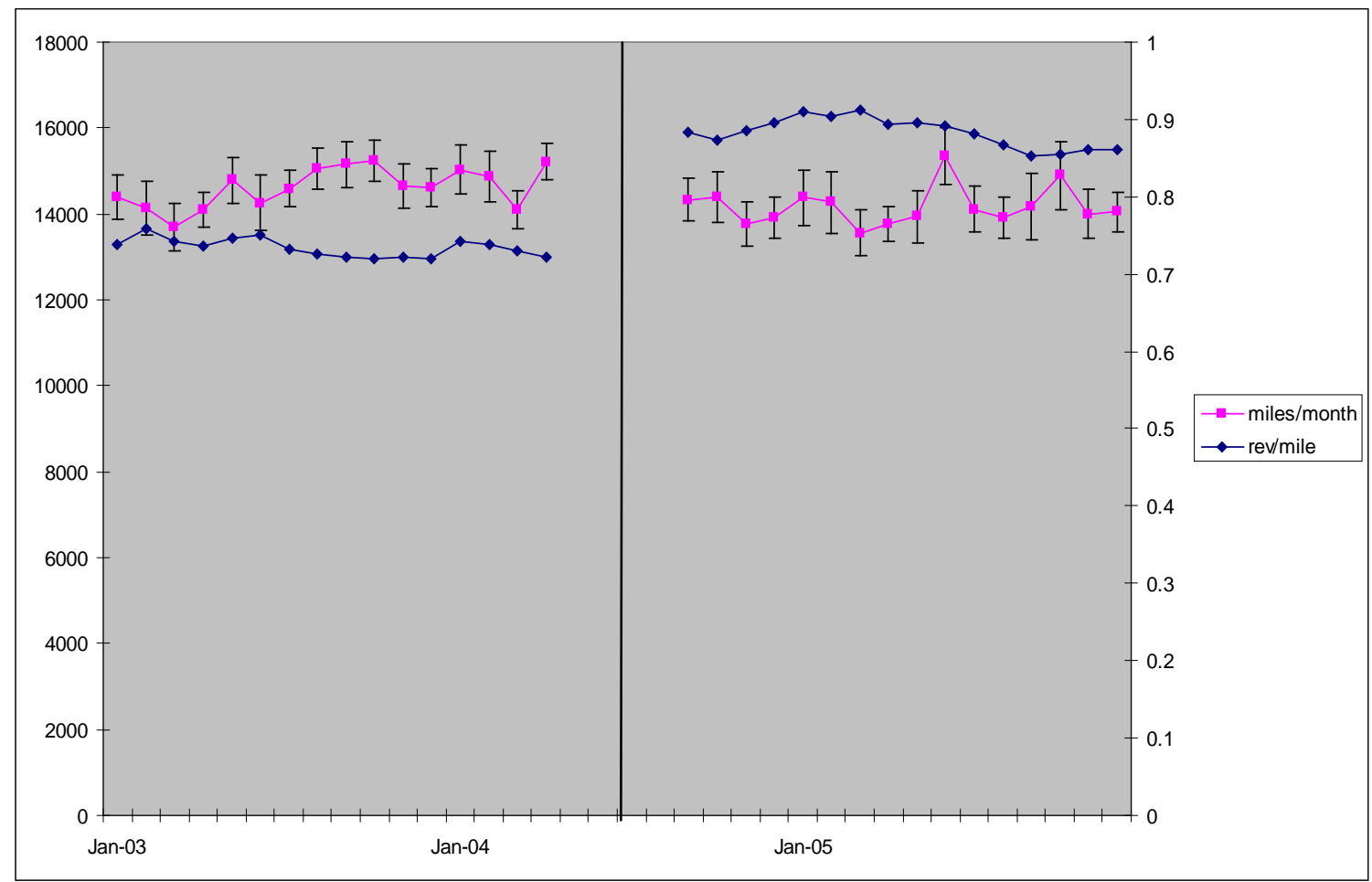

Appendix: Timeline regarding taxi decisions after 1998:

May $13^{\text {th }}, 1998: \quad$ city wide taxi drivers strike

May $28^{\text {th }}$, 1998: $\quad$ city wide taxi drivers strike

http://socialjustice.ccnmtl.columbia.edu/index.php/Alliance_Achie

vements

...Labor Supply Project\Alliance_Achievements.htm

March 2002:

New York City Taxi Workers Alliance organized forum to hear taxi driver's stories of their financial deterioration after September 11. Federal Emergency Management Agency had assisted taxi garages and brokers but not the drivers and at this hearing, FEMA officials heard the taxi drivers' stories. Soon after, FEMA opened a new Rental and Mortgage Assistance program- over 2,000

drivers participated.

http://socialjustice.ccnmtl.columbia.edu/index.php/Alliance_Achie vements

...Labor Supply Project\Alliance_Achievements.htm 
September $29^{\text {th }}$, 2003: “A group representing thousands of taxi drivers said it would begin to push harder for an increase in fares, after a broad survey of drivers found that many -- facing higher gas prices and a weak economy -- are increasingly unable to support themselves with their jobs. The survey, to be released today, included 581 drivers who were interviewed at Kennedy International and La Guardia Airports last winter. It was the first time such a large group had been interviewed by the New York Taxi Workers Alliance, which represents 4,800 of the more than 40,000 licensed taxi drivers in the city." http://query.nytimes.com/gst/fullpage.html?res=9F02E1D7103DF9 3AA1575AC0A9659C8B63

October 20 $0^{\text {th }}$, 2003: “A group representing thousands of taxi drivers in New York City is threatening a strike if the Taxi and Limousine Commission does not enact its first fare increase in seven years." http://query.nytimes.com/gst/fullpage.html?res=9407E5DE113EF9 33A15753C1A9659C8B63

January $1^{\text {st }}$,2004: "A formal study ordered by the city has essentially cleared the way for the largest taxicab-fleet expansion in nearly 70 years. It concluded that adding 900 cabs over the next three years would not pose environmental concerns and indicated that a moderate fare ease would probably assuage taxi owners."

"The intention is for 300 cabs to be added in each of the next three years, with the first group expected to be cruising city streets by June.”

http://wirednewyork.com/forum/showthread.php?t=4273 ...Labor Supply Projectlshowthread.php.htm

January $12^{\text {th }}$, 2004: "In recent months, drivers have threatened to strike if the fare is not increased. Officials are currently proposing a 25 percent hike.” http://www.gothamgazette.com/print/833 ...Labor Supply Projectl833.htm

January $28^{\text {th }}$, 2004: Taxi and Limousine Commission officially proposes taxi fare adjustment and service improvements. http://www.nyc.gov/html/tlc/html/news/press04_01.shtml ...Labor Supply Projectlpress04_01.html

"The proposal comes in the midst of environmental reviews for issuance of 900 additional taxicab licenses over three years, with the first batch of 300 planned for issuance by the end of the current fiscal year on June 30" http://www.gothamgazette.com/article/transportation/20040224/16 1889 


\section{...Labor Supply Projectl889.htm}

March 30 ${ }^{\text {th }}$, 2004: Taxi and Limousine Commission officially approves a fare increase of more than 26 percent, to take effect on Monday, May $3^{\text {rd }}$.

http://query.nytimes.com/gst/fullpage.html?res=9502E7DB1739F9

32A05750C0A9629C8B63\&sec $=\&$ spon=\&pagewanted=print ...Labor Supply Projectlfullpage.html

"Most of the increase will end up in drivers' pockets, because the commission also ruled that lease caps - the maximum amount that fleet owners can charge drivers - can be raised by only 8 percent.” http://wirednewyork.com/forum/showthread.php?t=4273 ...Labor Supply Projectlshowthread.php.htm “The New York City Taxi and Limousine Commission (TLC) today unanimously approved a proposed fare adjustment, as well as a package of service improvements designed to enhance the taxi riding experience. The new fare formula will be in effect as of 12:01 a.m. Monday, May 3, 2004.” http://www.nyc.gov/html/tlc/html/news/press04_03_a.shtml ...Labor Supply Projectlpress04_03_a.html

April 16" ${ }^{\text {th }}$ 2004: “On April 16, bids for 174 medallions from corporations (medallion and/or fleet owners) were accepted."

April 23 ${ }^{\text {rd }}$, 2004: $\quad$ "On April 23, 126 more new medallions were sold at a second bid opening for individuals. ..”

"On April 16 and 23, the New York City Taxi and Limousine Commission (TLC) opened some 664 bids for a total of 300 new yellow taxi medallions being auctioned by the city." http://www.unitedspinal.org/publications/action/2004/06/25/newtaxi-medallions-sold-no-access-achieved/ ...Labor Supply Project\Action Online » Blog Archive » New Taxi Medallions Sold, No Access Achieved.htm

May $3^{\text {rd }}$, 2004: $\quad$ Fare increase comes into effect. http://www.allbusiness.com/transportationcommunications/transportation-services/4156824-1.html ...Labor Supply Project|4156824-1.html

May $4^{\text {th }}, 2004: \quad$ Fare increase noticeable in the data. 